\title{
Return of the Talking Heads
}

\author{
Entering the Third Wave of Television News Dramaturgy
}

\author{
Kenneth Reinecke Hansen, Peter Bro \& Ralf Andersson
}

\begin{abstract}
The present article suggests that the brief history of Western television news dramaturgy can be expounded as three major waves: from the early days of the talking heads in the studio, over the narrativization of the field report to a (re-)current studio- and field-based talking heads format. In order to analyze the latest development entering the third wave, we propose a theoretically based dramaturgical model for the television news item. The analysis concludes that, with the current 'return' of the talking heads format, the pre-produced and pre-packaged bulletin program about past events is dissolving and transforming into an evaluative present- and future-oriented update format that resembles the 24-hour newsonly channels. Production time merges with broadcast time so that the uncertainty of live spreads to the dramaturgy.
\end{abstract}

Keywords: dramaturgy, live interview, narrative, television journalism, television news item, television news report

\section{Introduction}

In most of the Western world since the late 1980s, television journalism has been dominated by a strong norm of telling the news in narrative formats with distinct storylines and visuals, cf. the principles of visual storytelling (Everton 1999, Baym 2004) and the adaptation of various structuralist-narratological and dramaturgical models in the training of television journalists (Everton 1999, Larsen 2003, Hansen 2013, Larsen and Frederiksen 2014). Even though the notion of 'narrative' might be debatable in that connection, it is true that these news stories have typically been researched and told by one narrator, the journalist. In this regard, the talking heads format (Morse 1985) that dominated early television has often been considered to be of low quality or, at best, a workaround solution to delivering the news (Comstock 1980: 43).

However, current television journalism is challenged by a number of changes in news technology and news markets (Anderson et al. 2012) with digitalization/convergence, increasing competition (Montgomery 2007: 18, $184 \mathrm{f}$.) and on-demand viewership changing viewer behavior. For instance, in Denmark, the two public service television stations, DR and TV 2, have lost 500,000 news viewers over the 2003-2013 period (Pedersen 2013), a considerable loss in a country with approximately 5.5 million inhabitants. Hence, radical changes are being made in news production routines (Bro et al. 2015). 
We propose that the form of television journalism should be understood as evolving through three waves and that the latest development marks in many regards a return of the talking heads tradition. Our main focus is (entering) the third wave, addressing the research question: What are the dramaturgical consequences of returning to a talking heads format for the news item?

The scholarly literature is limited in its descriptions of the dramaturgy, i.e. internal structure and course, of the television news item: how the news is told, in what order and by whom. Thus, in order to address the research question, we develop a dramaturgical model for the television news item based on discourse and genre analysis (e.g., Montgomery 2007, Martin and Rose 2008), narratology (e.g., Labov and Waletzky 1967, Genette 1980), and prescriptive journalism textbooks (e.g., Everton 1999).

Our focal point is an illustrative case from Denmark that has parallels in countries throughout the Western world: The larger of the two Danish public service television stations, DR, has faced the changes in the news environment by introducing a new workflow, framed The News Engine (corresponding roughly to the BBC's somewhat more adequate metaphor Newsgathering). With the news engine, a large section of DR's news division now comprises 'live teams' that are responsible for interviewing, shooting, etc., while other journalists edit the stories and prepare them for different platforms, and still other journalists - internally high-profile and publicly familiar correspondents - deliver live interviews (Andersson 2013). This is a very radical change in the working routines, as journalists used to be individually responsible for various steps in the production process, sometimes even all the steps, cf. the so-called video journalists (Everton 1999). With this case, we can study the recent development in television news dramaturgy, because the news engine quite abruptly introduced and accelerated the trend toward a return of the talking heads. Specifically, we analyze the recent development in the most essential part of the news engine: DR's television news bulletin program $T V$-Avisen (TVA), aired nightly at 6.30 p.m. As it turns out, the news engine is not solely to 'blame' for the changes in the form of TVA. Rather, the news engine is apparently accelerating a process that was already underway.

\section{Data and Methods}

The present findings stem from of a larger study on DR's news engine - and its consequences for the production process, journalists' roles and self-understanding, and the content of TVA (cf. Andersson 2013, Bro et al. 2015). The argument of the current study relies on a broad literature review and, more specifically, on quantitative and qualitative analyses of TVA in 20082011 and 2013.

The news engine was introduced on 1 September 2012. For the content analysis (cf. section 3), we compared the overall composition of TVA at $6.30 \mathrm{p} . \mathrm{m}$. from the same week (week 17) in 2008, 2011, and 2013. Two coders measured time spent on news reporting versus live elements, and enumerated sources being interviewed live.

Applying the dramaturgical model (presented in section 5), all of the news items from week 17 in all three years were analyzed with regard to their stage structure and how the stages were realized linguistically (cf. Montgomery 2007: 36). Due to the limited space in the present article, however, we mainly present qualitative analyses of major changes in dramaturgy of TVA between 2008 and 2013 (section 6). 


\section{Three Waves of Television News Dramaturgy}

Generally, the form of television journalism is and has been dependent on technological enablements and constraints. From the onset of television, cumbersome technology contributed to a strong talking heads tradition, where television news was presented from the studio, i.e. read out by the presenter or 'debated' in long monologues on a bland background (Barnhurst and Steele 1997: 48, Hjarvard 1999). Doing field reports was simply troublesome and expensive. Even when technology became more flexible, public service stations like DR insisted on the talking heads format for some time, at any rate up to the end of the Danish television monopoly in 1988. This format raised a scholarly critique that television news did not harness the media's potential for visual language (Graber 1990), which might also result from a certain institutional inertia. 'TV-Avisen' literally means 'The TV Newspaper'.

Nevertheless, when lighter technology was combined with deregulation and increased competition in the news market (Hjarvard 1999, Ytreberg 2001, Dunn 2005: 147), more edited field reports appeared, and the talking heads format was largely abandoned (Barnhurst and Steele 1997: 49, Baym 2004: 284), or rather, the two ways of delivering the news became competing 'schools' (Ytreberg 2001: $362 \mathrm{f}$.). In Denmark, a television journalist became a reporter, and as a whole, the evolution in the 1980-1990s can be characterized as increasing narrativization: The reports adapted narrative and dramaturgical models in order to sustain the viewer's attention, which until recently has been bound in real time, applying a range of narrative devices and ascending editing. These characteristics are seemingly contrasting: Reality is being segmented - literally cut to a greater extent, and this is a fragmentation. But at the same time, these fragments are packaged (Griffin 1992: 139) and framed into a tight angle linked together by the journalist's voice-over. The narrativization has thus been problematized, as it cuts up the sources' discourses into sound and image bites (Griffin 1992: 124-125, Hallin 1992; Barnhurst and Steele 1997, Sand and Helland 1998: 231, Baym 2004: 295, Eriksson 2006). Concurrently, however, it has been acknowledged because edited news reports are apparently easier to comprehend, retain and recall compared to live talk formats (Edwardson et al. 1981, Graber 1990, Brosius 1991, Snoeijer et al. 2002, Machill et al. 2007).

In recent years, the edited news report is declining and, concurrent with a rise in the much cheaper live interview, facilitated by the technically easier exchanges to various news fields. This is also documented in our preliminary content analysis of the overall composition of TVA at 6.30 p.m., showing that over the course of the 2008-2013 period, the amount of time spent on prerecorded news reports has decreased significantly, concurrent with a doubling of the total length of live elements, i.e. news presented live by the presenter from the studio, and live interviews (cf. Figure 1).

The graph suggests that the evolution toward 'more live' was already underway before the introduction of the news engine. However, the changes accelerated in 20112013, and in 2013, more time was in fact spent on live elements than on news reports. Compared to 2008, where reports outnumbered live elements at a 3:1 ratio, this change seems quite significant.

Furthermore, a large - and increasing - number of these live interviews were with DR's own staff members, i.e. "live, two-way affiliated interviews" (Montgomery 2007: $117 \mathrm{ff}.) .{ }^{1}$ The content analysis reveals that 68 percent of the live interviews were with 
Figure 1. Prerecorded News Reports versus Live Elements in TVA (per cent)

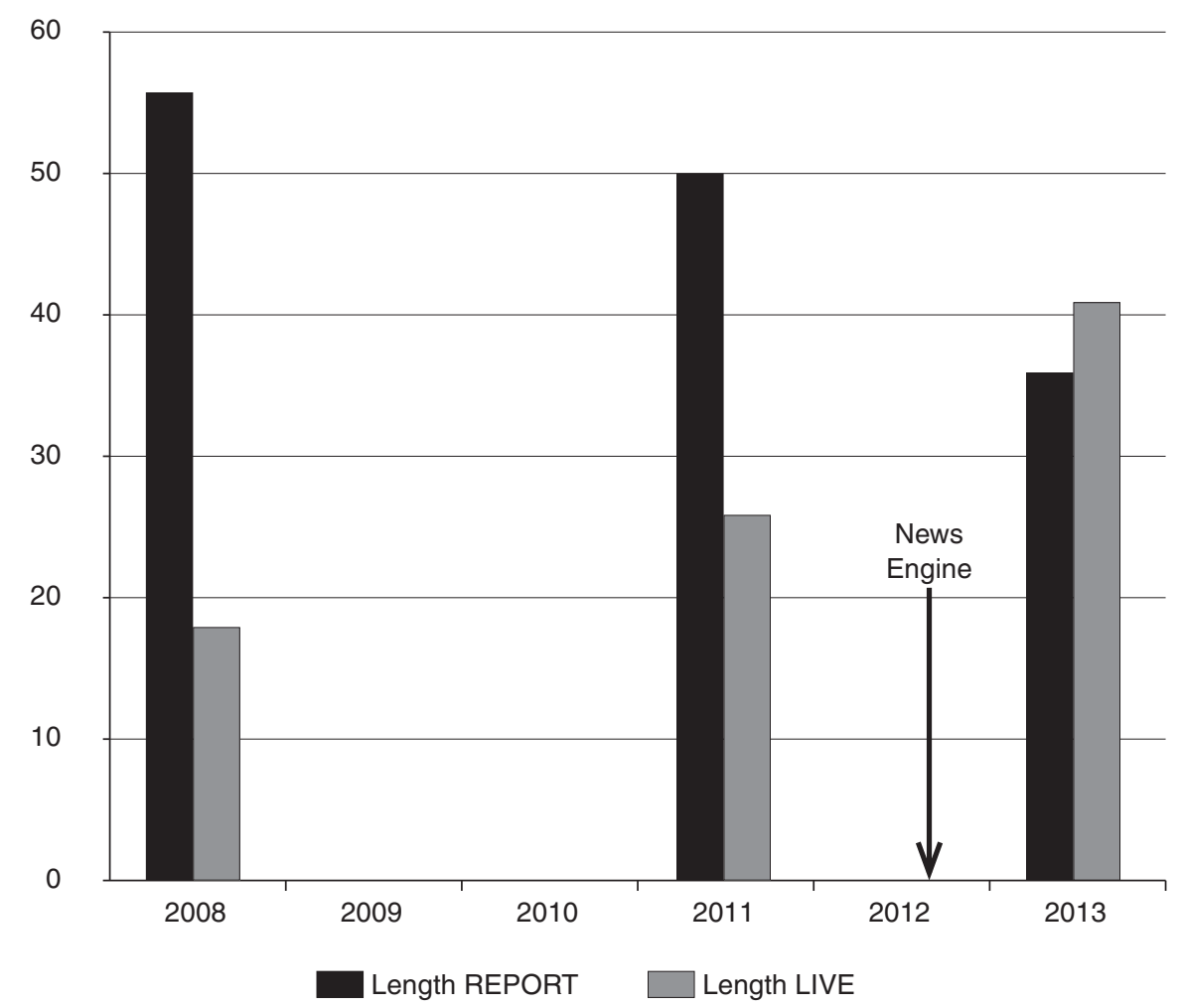

DR's own journalists in 2008 and 2011, whereas in in 2013, the corresponding figure was 75 percent. In other words, DR's own journalists and correspondents have in fact become the main source in TVA. This finding is in concordance with, e.g., Bucy and Grabe (2007: 665), who show that journalists were speaking on-air about twice as often as political candidates during the US presidential election campaigns in 1992-2004, and Kroon Lundell and Eriksson (2010), who find that journalists-as-interviewees are now more common than politicians-as-interviewees in British and Swedish television news (cf. also Baym 2004: 292, Tolson 2006: 68, Kroon Lundell 2010: 434). In content, these interviews most likely align with a general trend in which journalism is becoming increasingly interpretive (Schudson 1982: 100; Barnhurst \& Mutz 1997; Baym 2004: 292; Tolson 2006; Djerf-Pierre \& Weibull 2008: 209; Salgado \& Strömbäck 2012; Barnhurst 2013; Kroon Lundell \& Ekström 2013) and future-oriented (Ellis 2000; Jaworski et al. 2003; Neiger 2007). According to Salgado and Strömbäck, this interpretive journalism "is opposed to or going beyond descriptive, fact-focused and source-driven journalism [...] by journalistic explanations, evaluations, contextualizations, or speculations going beyond verifiable facts or statements by sources" (2012: 154).

\section{Is Television News Narrative?}

The recent decline in edited news reports has caused scholars to lament a loss of intelligibility. Ben-Porath, for instance, states that "[ $t]$ elevision news stands out as the most 
coherently organized form of news narrative" (2007: 418), and when turning to talking heads formats the result is "internal fragmentation of the news message" (p. 415, emphasis original; cf. also Griffin 1992: 139; Lewis 1994: 33; Barnhurst \& Mutz 1997: 19, Ellis 2000: 75). However, the - often presupposed - view that television news is in fact narrative has been challenged, even contradicted (e.g., Lewis 1994). Ytreberg finds that television news admittedly contains "several ingredients that are common to narratives (persons, places, events, causes) but seems to order them quite differently [...]" (2001: 359). And Montgomery argues that "the core principle of intelligibility in television news reports might be summed up as the convincing deployment of pictures - and, in this respect, narrative is only an occasional discursive resource [...]" (2007: 91). When television news reports are often considered narratives, cf. also common-sense concepts like news story, it is probably mainly due to the voice-over format (Montgomery 2007: 89), but also the temporal organization of content (Martin \& Rose 2008: 244). Television journalists narrate about (communicative) events that occur or have occurred in time, in a format that expands in time and with time as a composition principle. Admittedly, chronology is ruptured and reorganized, which is why (here written) "news stories are opposed to other types, in that they privilege textual organisation over temporal sequence" (ibid., 81), but this does not necessarily make the news item less narrative. From a narratological perspective, the news item thus resembles other narratives in that it constructs a narrative on the basis of an underlying chronological story (Genette 1980). It is, however, obvious that this mainly applies to the report; as the report is replaced by live elements, recency (event time) merges with currency (reader time) and immediacy (writer time) in "a precarious performance" (Barnhurst 2011: 109). Thus, narratively, the "frequent selection of the present tense helps to collapse the distance between the news field and its report in such a way that undermines chronology." (Montgomery 2007: 93).

From our perspective, the most severe objection to considering television news items narrative is that they most often comprise "running news stories where the resolution of plotlines is simply not available because events have only partially unfolded" (Ytreberg 2001: 365; see also Bell 1991: 154-155, Lewis 1994: 28 f., Scannell 1996: 84, Ellis 2000: 78, Dunn 2005: 145, Montgomery 2007: 91). The news is literally 'going on' as it is told. Thus, the items are mostly open-ended and respond to the news' latest developments and possible futures (Ellis 2000). In addition, television news is in fact not - or rarely - composed around suspense and an "at least minimally complicated detour, the intentional deviance, in tension, which is the plot of narrative" (Brooks 1984: 104). Rather, television news delivers an adequate summary already in the news kernel (Montgomery 2007: 39), resembling the inverted pyramid (Lewis 1994: 29 f., Ytreberg 2001) with a more uncertain and frayed ending. On the other hand, the narrativization of television journalism has carried metaphors like package (Baym 2004: 281-2) and wrap (Everton 1999: 38), indicating that journalists have sought to, at least dramaturgically, close the items in a narrative-like manner (Lewis 1994: 29).

The more fundamental challenge to the view of television news as narrative is connected to a perception that "television as a form tends towards [...] uncertainty and openness" (Ellis: 2000: 82), deriving from the fact that "the domestic setting in which it is viewed, makes television eminently interruptible" (Dunn 2005: 130). Accordingly, television narrative is, generally speaking, "more diffuse, more fragmentary, more episodic and iterative than cinema" (Montgomery 2007: 90), given that cinema consti- 
tutes a "fictional totality" (ibid. 225). Because television news is composed of coherent segments at best (Dunn 2005: 146), these should rather be compared with the mostly brief and incomplete narratives of everyday life (Labov and Waletzky 1967, Labov 1972, 1997, Martin \& Rose 2008). These can be grasped as open or discursive genres, not (only) to be defined in "properties of talk or text "itself" [...] but rather in terms of aspects of the context" (van Dijk 2008: 149). Thus, it is possible for a news report to be coherent, even if it lacks text-internal cohesive ties: The verbal track refers both homophorically/intertextually to presupposed knowledge of the world and former news ('the so-called X-affair') and endophorically/intermodally to the more or less parallel pictures, due to "a presumption of shared reference between the verbal track and the visual track" (Montgomery 2007: 95).

\section{A Dramaturgical Model for the Television News Item}

In this section, we present a fundamental dramaturgical model for the television news item, mainly based on Montgomery's distinction between axis of presentation and axis of reporting (2007: 77), as well as on a distinction between modes and stages.

Within the narrative presentation form, which has time as the organizing principle in indirect address, we find it useful to operate with the two modes of dramatic and epic. The former can be characterized as a (causal-) temporal account without narrator, presented scenically and linearly in an 'ongoing now' (mimesis), and the latter as a causal-temporal account with narrator, narrated in the past tense, thus allowing curved leaps in time (diegesis).

Accordingly, we can localize a didactic presentation form, which is predominant in television journalism and is causally-logically structured in direct address (Larsen 1995: 90 f.). Within the didactic presentation form, we uphold a distinction between a descriptive mode, which instructively lays out information by declining significance according to the news angle (cf. Ytreberg 2001: 358; Machill et al. 2007: 193; Montgomery 2007: 78; roughly corresponding to the information mode in Ekström 2000), and a commentary mode, which analyzes and interprets the news and its (possible) consequences (Bell 1991: 170; Montgomery 2007: 109).

The descriptive mode particularly manifests itself in the kernel, in which the presenter addresses the viewer in a monological and formal, i.e. non-evaluative, discourse, a mode that also applies to much of the report's voice-over (Ytreberg 2001: 360-1; Montgomery 2007: $84 \mathrm{f}$.), while the commentary mode is most apparent in the live two-way affiliate interview in a dialogical, informal-conversational and evaluative discourse marked for modality (Montgomery 2007; cf. also Scannell 1996, Labov 1997, Haarman 2004, Tolson 2006: 63, Ekström \& Kroon Lundell 2011). The two narrative modes mainly appear in the reports (and particularly in the case of a motor ${ }^{2}$ ): epic when voice-over and sound bites are recounting, and dramatic when clean sound and short sound bites 'unmediatedly' display scenes in an ongoing present.

However, more specific knowledge about the course of the news item is rather limited, mainly because journalism research has been remarkably sparse when it comes to television news dramaturgy (Langer 1998: 39-40). At least in Denmark, the training of television journalists has largely built on experience-based and prescriptive models, the most common until recently being the Hollywood model as characteristically called 
(berettermodellen in Danish) - and its compressed edition of the Canadian The Grid's four stages: Hook, Context, Development, Wrap ${ }^{3}$ (Everton 1999: 35 f., Larsen 2003: 169 f.). The Grid prescribes that Context, i.e. essential background information, should be located in the first part of the news item, and Development in the second part. Context roughly corresponds to Orientation in Labov and Waletzky's terminology, and Development to Complication and Resolution (Labov \& Waletzky 1967: 32, 39), even though proper Resolution rarely applies to (hard) news (Bell 1991, 154-5). Between Context and Development, a disruption (Martin \& Rose 2008: 50 ff.) usually occurs, typically marked in the speech with a "but", "however", or similar.

Hook and Wrap - the latter roughly equivalent to Coda (Labov 1972: 365) - are not obligatory stages in television news. It is, however, Kernel - corresponding approximately to Abstract (Bell 1991: 149; Labov 1997: 5) - that, strictly speaking, is the only obligatory stage (Bell 1991: 149, Montgomery 2007: 83). Kernel can be read solely from the studio or augmented with prerecorded footage and/or sound bites, i.e. "live voice-over" (Dunn 2005: 149). Finally, we must embody an independent Evaluation stage located after the report in a live interview or as dispersed "waves of evaluation that penetrate the narrative" (Labov 1972: 369). With these remarks, we can assemble the four modes and the four stages in a prototypical dramaturgical model for the television news item, cf. Figure $2 .{ }^{4}$

Figure 2. A Dramaturgical Model for the Television News Item

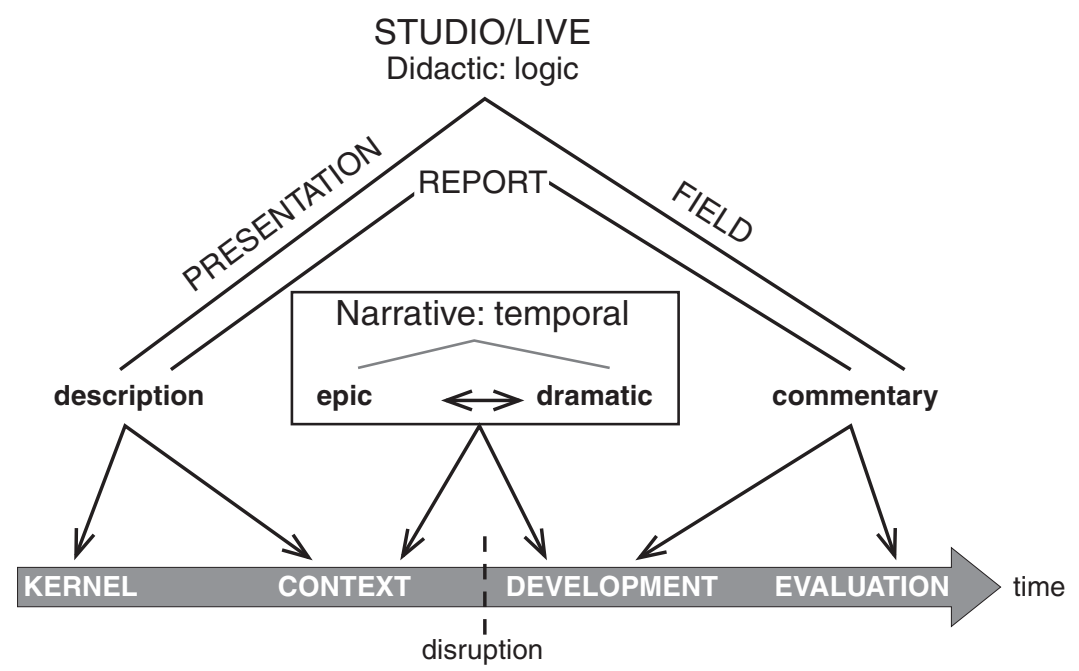

If we regard the three waves in the perspective of the model, the first wave was largely characterized by description, weighting Kernel and Context. The second wave expanded the narrative - this was the heyday of The Grid, so to speak. In the third wave, cf. section 6 below, Kernel is expanded (adding several devices: footage, graphs, etc.) concurrently with an expanding Evaluation stage. Narrative is thus diminished, due to the contracting report, and because Evaluation "suspends the forward movement of the action" (Labov 1997: 6). 


\section{TVA Dramaturgy Entering the Third Wave}

The qualitative analysis below takes its point of departure in a typical 2008 news item, followed up by typical developments in the 2013 material. Thus, although there are more dramaturgical similarities than differences in the analyzed items over the three years, we focus on the most significant differences between 2008 and 2013 in an attempt to identify the dramaturgical consequences of the returning talking heads.

The 2008 news item with the subject heading 'Torture' (TVA, 21.4.2008) is a political top story, comprising a packaged report followed by a live interview with the Danish Minister of Justice at the time. The Kernel is read from the studio: ${ }^{5}$

\section{Excerpt 1}

Presenter: Minister of Justice Lene Espersen is now considering expelling terrorist suspects to countries that practice torture. Denmark merely needs an agreement with those countries in which they promise not to carry out torture, after a socalled diplomatic guarantee, although not legally binding. But the proposal faces some opposition.

Characteristically, the Kernel is short and summarizing, and miming the dramaturgy of the news report and live interview: The news itself ("now") and its Context is presented, then disrupted ("although", "But"), and finally Development is announced: The proposal faces opposition. The mode is descriptive and instructive ("a so-called diplomatic guarantee"). Likewise, in the report, the proposal and its background are presented in the first half, after which a journalistic stand-up overlaps to the second half, where spokespeople from opposing political parties contradict the proposal, to be discussed finally with the Minister herself.

The report has an independent Hook (footage of the 11 September 2001 terrorist attack in New York), followed by Context:

\section{Excerpt 2}

Reporter: Since the attack on the World Trade Center in 2001, we have struggled to make rules and regulations to restrain the terror threat. Recently, two Tunisians were expelled for plotting the assassination of the illustrator Kurt Westergaard. But now they perhaps cannot be expelled because they risk torture in Tunisia. But Lene Espersen has a plan.

Lene Espersen: I will examine whether [...]

The transition to the Context stage is clearly marked, visually (terror attack) and verbally (marked theme). Here, Context is about past events, realized in the present perfect and past tenses (and the proposal itself in the present and future tenses). The reporter narrates epically from a distant past (2001), to "Recently" up to "now."

After Context, the report goes into Development via a visually marked disruption: a stand-up with the reporter in the picture:

\section{Excerpt 3}

Reporter: But the idea faces severe resistance, both from organizations such as Amnesty International, who believe it is completely impossible to make reliable agreements with states that allow torture, and from the opposition here in Folketinget [the Danish Parliament]. 
The disruption is also discursively marked with a conjunction ("But"), and compared with the Kernel, characterized by a more evaluative discourse ("severe resistance"; "completely impossible").

Development itself consists of sound bites with two opposition politicians. Unlike Context, this stage is characterized by resistance (e.g. "We are against ...") and dilemmas. Because the question is fundamental, the tense is mainly the timeless present.

Finally, the report is followed by a live (on tape) interview with the Minister. This is the Evaluation stage testing the proposal against some of the objections. The question design is prepared to challenge counterarguments, logically built up of legal practices from different (comparable) countries: "When you say [...] yet you will expel people [...];" "But also a country like Sweden [...];" "But, for instance, in Canada [...]."

Thus, 'Torture' consists of a summarizing Kernel, a packaged report with clearly marked stages, and a live interview commenting on the statements of the report. These characteristics position the dramaturgy of 'Torture' in the second wave, even though live seems to have an independent value (the final interview could have been edited into the report).

When entering the third wave - in this study represented by the 2013 week - several dramaturgical changes can be observed. First, a significantly expanded Kernel (live voice-over) becomes more common, most obviously in items with direct transition to a live interview and (thus) without a prerecorded report. This is the case in 'Homowedding' (TVA, 23.4.2013), where the following is read in Kernel while pictures from and demonstrations outside the French Parliament are displayed:

\section{Excerpt 4}

Presenter: We are going to France where the politicians a short while ago decided that homosexuals will be allowed to marry and to adopt children. 331 politicians voted in favor. 225 voted against [pause].

Here the law is, eh, cheered on by the supporters, eh, passed. There has otherwise been great opposition in the National Assembly during, eh, the reading of the law, and, eh, large parts of the population [pause] have been against it. There have been major demonstrations.

Sorry, that was a slightly confusing text. I hope you got most of it [laugh]. In any case, the law is passed. Good evening, Bjørn Willum. The debate has been fierce [reporter: Good evening] among politicians, and here in the past week, there have been lots of demonstrations against this law. Who has been so much against it in France?

The overall structure is largely the same as in 'Torture': starting with the news (the passing) and Context (stating where, who, when, and what, cf. Bell 1991: 151), followed by a disruption ("otherwise") and Development (the resistance). But Kernel is longer - not just a summarizing Abstract - with current and dramatic footage displayed. Moreover, the uncertainty of the newly arrived images ("a short while ago") spreads to the presenter's discourse in the form of hesitation, self-interruptions, etc.

Second, the direct transition from Kernel to live interviews often results in an omission of the Context stage, which is presupposed or delivered live from the studio and/ or the news field. The latter is the case in 'Homo-wedding', cf. the reporter's answer following the question in Excerpt 4: 


\section{Excerpt 5}

That can be put quite briefly: It is members of France's large Catholic majority, then it is members of the right-wing opposition, and then it is people from the extreme right.

This Context stage is summative, descriptive (except for the evaluative "extreme"), and ordered logically, not epically. But what the reporter delivers is still a report - although not prerecorded - about (recent) past events.

Third, Development is also often executed live. But since the reporter sometimes lacks information, she/he has to 'thread water', cf. the live interview from Boston in Excerpt 6 ('Terror in Boston' TVA, 22.4.2013):

\section{Excerpt 6}

Reporter: $[\ldots]$ Because the Americans have many questions they would like to ask the 19-year-old here in the hospital.

Presenter: And some of the questions could perhaps be about whether he had more plans for more attacks, as we hear that this is what the US police is saying now, that in fact he had. What do we know about these plans?

Reporter: American police is quite convinced that the two brothers had intended to carry out more terrorist attacks [...]. But [...] that is probably the kind of question they are asking Dzhokhar Tsarnaev right now.

The reporter mainly reiterates what "we" already knew, cf. presenter's "we hear that this is what the US police are saying now", after which he - uncertainly - points to the ongoing "right now." Because the result of the examination is, ipso facto, unknown, TVA must rely on conjecture, cf. irrealis past tense "could" and the modality markers "perhaps", "quite", and "probably."

Fourth, this uncertainty also characterizes the expanding Evaluation stage, which often incites predictions and speculations about the future, the latter usually containing a hypothetical scenario in the form of a conditional clause (Hansen \& Blom 2014). In the exchange in Excerpt 7 ('IT Crime', TVA, 22.4.2013), the speculative question design induces, not facts, but what is imaginable as a worst-case scenario (cf. Neiger 2007: 314):

\section{Excerpt 7}

Presenter: And just very briefly, Claus, how bad can this end up, this, if what FE [intelligence agency] dreads ends in disaster?

Reporter: Try to imagine if somebody breaks into the Danish banking system [...].

That would, in reality, destabilize our society.

In a sense, such future-orientation is a logical consequence of the uncertainty of the ongoing present, because, as phrased by Neiger, "when new information on the event itself is no longer available, only its future outcomes can be deemed new" (Neiger 2007: 319 ). It contributes to the open-endedness in somewhat the same way that narrative builds tension through expectancy and suspense (Scannell 1996).

Fifth, the live format has the ability to prolong deadlines, making the entire news program open-ended. This is demonstrable in a characteristic new segment before the last item where the presenter summarizes, e.g. (TVA, 26.4.2013): 


\section{Excerpt 8}

Presenter: We are in progress with TV-Avisen, and for new viewers, here are today's headlines $[\ldots]$.

In this roundup, TVA displays footage and sound bites from the program so far. Thus, TVA does not count on being viewed from the beginning.

Sixth, due to the uncertainty of live, the presenter must repair verbally in a strategy including, among other things, coherence through question design (cf. the presenter's anaphoric precision, "some of the questions", from the reporters "many questions" in Excerpt 6), technology as an 'excuse' for lack of coherence (cf. Excerpt 4), and summaries along the way or, as in Excerpt 9 (TVA 25.4.2013), at the end of a news item:

\section{Excerpt 9}

Presenter: And then, let's just recap what today's intervention means for all the pupils who are now waiting to get back to school.

Previously, summaries were mainly located in Kernel (Bell 1991: 148 f.). By spreading them, the journalists are better able to survey the news flow while broadcasting, and the viewers are better able to switch on and off.

Seventh, and finally, with the more exposed production process and the increase in live talking heads, TVA has, to some extent, 'solved' a fundamental television journalistic problem, which is "that the events journalists are to depict have already happened and cannot be visualized" (Ekström 2000: 475). By commenting on events and their possible futures, the screen is occupied by talking heads. In return, however, these pictures most likely lack important realism, and emotionality (Graber 1990: 152), correspondence with the text/speech (Brosius et al. 1996: 184), and documenting visual proof (Larsen 2003: 157, Hansen 2013: 46). Moreover, the location of the talking heads is not always journalistically or dramaturgically motivated. The presence in Boston might, admittedly, substantiate the eyewitness status, but often the reporter is seen in front of a closed door somewhere in Copenhagen a few kilometers from the studio - or in another studio - and such "pictures rarely contribute any additional information to the soundtrack [...]" (Griffin 1992: 135).

\section{Conclusion}

In the present article, we have suggested that the dramaturgy of television journalism can be understood in three waves: from the early days of the talking heads in the studio, over the narrativization of the field report to a recurrent studio- and field-based talking heads format, the latter, in the TVA context, accelerated by the news engine.

Our analyses indicate that when entering the third wave, the dramaturgy extends Kernel, diminishes or presupposes Context or delivers it live, emphasizes Development in the ongoing present, and increases Evaluation of present events and their possible futures. Production time merges with broadcast time and event time so that the uncertainty of live spreads to the dramaturgy. Thus, the presenter becomes more involved in delivering the news and verbally repairing coherence. As also mentioned by other scholars (e.g., Ellis 2000, Tolson 2006, Montgomery 2007), it seems that the television news item is moving from a somewhat closed, 'packaged' dramaturgy to a more fragmented and permanently open flow structure, so that the pre-produced and pre-packaged bulletin 
program about past events is dissolving and transforming into an evaluative present- and future-oriented update format that resembles the 24-hour news-only channels.

In a Danish context, this evolution is also reflected in - and/or caused by - the fact that The Grid in recent years has been challenged by The PCP model (PKP-modellen in Danish) with the stages Premise, Consequence, Perspective (Larsen \& Frederiksen 2014, our translation). The two models have the same compositional logic, but also a very distinctive difference: While The Grid has a closed dramaturgical structure in the Aristotelian sense, cf. Wrap, the PCP model prescribes an open-ended structure where Perspective must provide "a prospective estimate on what will happen to the premise set out in the first phase" (ibid., 2014: 36, our translation). The prescriptive dramaturgy has thus adapted to a highly competitive news environment with expanded airtime and (thus) prevailing talking heads.

On the whole, one might ask whether this trend is beneficial to television news. Generally, we do not believe that the solution to the crisis in television journalism is more live interviews with in-house journalists, especially not if employment of talking heads is not motivated by the content and/or dramaturgy. In fact, experimental reception studies have suggested that viewers not only appreciate edited news reports compared to live formats (Snoeijer et al. 2002), but moreover that they recall (ibid.), comprehend and retain the report better (Edwardson et al. 1981, Graber 1990, Brosius 1991, Snoeijer et al. 2002, Machill et al. 2007). On the other hand, television journalism must adapt to ondemand viewership. The solution may be a division of labor known from other kinds of journalism: brief updates combined with longer and well-narrated background formats.

Theoretically and methodically, we address the need for research-based news dramaturgy. The prevalent dominating prescriptive formulas "are often limited to apodictic statements" (Machill et al. 2007: 191), which might also be the main reason why news items are so strikingly uniform. The developers of the PCP model, for instance, states that the three stages "together and quite naturally [sic] will create the proper dramaturgy that can convert all journalistic stories to well-functioning television narratives" (Larsen \& Frederiksen 2014: 36, our translation and italics). Such statements might constitute a straitjacket, hardly conducive to the creative development of television news dramaturgy in a time of rapidly changing viewer behavior.

\section{Notes}

1. In concordance with Montgomery (2007), we term these exchanges interviews, although they are more symmetrical than other interview types and differ in degree of interaction (if any), cf. that Kroon Lundell suggests "intraprofessional dialogues" as the superordinate term (2010: 435).

2. An epic or dramatic motor can be defined as a systematized plot carried by an exemplar or the journalist her-/himself. Hence, a motor is an intervention (reconstruction or reenactment of event, interference with event, construction of new event) into the reality narrated, aiming at establishing a parallel or embedded narrative with the exemplar or the journalist as leading character (Ekström, 2000: 475; Larsen, 2003: 164-165; Hansen, 2004: 230; 2013: 228).

3. From this point, we indicate stages with initial capital.

4. The model in Figure 2 is linear, given that the order of Context and Development is obligatory. Additionally, another significant, circular stage model can be identified, structured by a more or less chronological motor under which Context is installed as 'pockets' (Hansen, 2013: $236 \mathrm{f}$.). We do not elaborate on this model here because the trends we stress below are virtually identical for the two models.

5. All excerpts have been translated, and orthography has been normalized. In Excerpt 4, significant pauses have been indicated. 


\section{References}

Anderson, Chris, Bell, Emily, \& Shirky, Clay (2012) Post-industrial Journalism: Adapting to the Present. Columbia University: Tow Center for Digital Journalism.

Andersson, Ralf (2013) Den industrialiserede nyhedsproduktion: En undersøgelse af den ændrede produktionsform i DR nyheder [The industrialized newsproduction: An investigation of the changed production in DR]. Odense: University of Southern Denmark.

Barnhurst, Kevin G. (2011) The Problem of Modern Time in American Journalism. KronoScope 11: 98-123.

Barnhurst, Kevin G. (2013) Newspapers experiment online: Story content after a decade on the web. Journalism 14: 3-21.

Barnhurst, Kevin G., \& Mutz, Diana (1997) American Journalism and the Decline in Event-Centered Reporting. Journal of Communication 47: 26-53.

Barnhurst, Kevin G., \& Steele, Catherine A. (1997) Image-Bite News: The Visual Coverage of Elections on US Television 1968-1992. The Harvard International Journal of Press/Politics 2: 40-58.

Baym, Geoffrey (2004) Packaging Reality: Structures of Form in US Network News Coverage of Watergate and the Clinton Impeachment. Journalism 5: 279-299.

Bell, Allan (1991) The Language of News Media, Oxford: Blackwell Publishers.

Ben-Porath, Eran N. (2007) Internal fragmentation of the news: Television news in dialogical format and its consequences for journalism. Journalism Studies 8: 414-431.

Bro, Peter, Hansen, Kenneth Reinecke \& Andersson, Ralf (2015) Improving Productivity in the Newsroom?: Deskilling, reskilling and multiskilling in the news media, Journalism Practice, DOI: 10.1080/17512786.2015.1090883

Brooks, Peter (1984) Reading for the plot: Design and intention in narrative, Oxford: Oxford University Press.

Brosius, Hans-Bernd (1991) Format effects on comprehension of television news. Journalism \& Mass Communication Quarterly 68: 396-401.

Brosius, Hans-Bernd, Donsbach, Wolfgang, \& Birk, Monika (1996) How do text - picture relations affect the informational effectiveness of television newscasts? Journal of Broadcasting \& Electronic Media 40: 180-195.

Bucy, Eric P., \& Grabe, Maria E. (2007) Taking television seriously: A sound and image bite analysis of presidential campaign coverage 1992-2004. Journal of Communication 57: 652-675.

Comstock, George (1980) Television in America, Beverly Hills: Sage Publications.

Djerf-Pierre, Monika, \& Weibull, Lennart (2008) From Public Educator to Interpreting Ombudsman. Regimes of Political Journalism in Swedish Public Service Broadcasting 1925-2005. In: Strömbäck Jesper, Ørsten, Mark \& Aalberg, Toril (eds) Communicating Politics. Political Communication in the Nordic Countries. Göteborg: Nordicom.

Dunn, Anne (2005) Television news as narrative. In: Fulton, Helene; Huisman, Rosemary, Murphet, Julian, et al. (eds) Narrative and Media. New York: Cambridge University Press, 140-152.

Edwardson, Mickie; Grooms, Donald, \& Proudlove, S. (1981) Television news information gain from interesting video vs. talking heads. Journal of Broadcasting \& Electronic Media 25: 15-24.

Ekström, Mats (2000) Information, storytelling and attractions: TV journalism in three modes of communication. Media, Culture \& Society 22: 465-492.

Ekström, Mats, \& Kroon Lundell, Åsa (2011) The joint construction of a journalistic expert identity in studio interactions between journalists on TV news. Text \& Talk 31: 661-681.

Ellis, John (2000) Seeing Things: Television in Age of Uncertainty, London and New York: I.B. Tauris Publishers.

Eriksson, Göran (2006) Framing of Politicians' Answers and the Mediazation of Politics. A Historical Comparative Study of the Discourse Practice of Framing in News Stories. In: Ekström, Mats; Kroon, Åsa, \& Nylund, Mats (eds) News from the Interview Society. Göteborg: Nordicom.

Everton, Neil (1999) The VJ Handbook, Canada: Canadian Broadcasting Corporation. Training \& Development. Genette, Gerard (1980) Narrative discourse: An essay in method, Ithaca, N.Y.: Cornell University Press.

Graber, Doris Appel (1990) Seeing is remembering: How visuals contribute to learning from television news. Journal of Communication 40: 134-156.

Griffin, Michael (1992) Looking at TV news: Strategies for research. Communication 13: 121-141.

Haarman, Louann (2004) 'John, what's going on?' Some features of live exchanges on television news. In: Partington, Alan; Morley, John, \& Haarman, Louann (eds) Corpora and Discourse. Bern: Peter Lang, 71-87.

Hallin, Daniel C. (1992) Sound bite news: Television coverage of elections 1968-1988. Journal of Communication 42: 5-24.

Hansen, Kenneth Reinecke (2004). 'Reality' in TV journalism: Dramaturgy of the Motor. About the Relationship between TV Journalistic Production and Dramaturgy in Current Affairs Features. Nordicom Review 25: 227-236.

Hansen, Kenneth Reinecke (2013) Aktualitetsfeaturens dramaturgi. En analyse af forholdet mellem produktion og dramaturgi i den emnealmene aktualitetsfeature [Dramaturgy of the Current Affairs Feature: An Analysis of the Relationship between Production and Dramaturgy in the General Current Affairs Feature] Odense: Syddansk Universitetsforlag. 
Hansen, Kenneth Reinecke, \& Blom, Jonas Nygaard (2014) Wondering what the future holds. A testable and replicable approach to coding and identifying future-oriented guesses in journalism. ICA's 64th Annual Conference. Seattle, Washington.

Hjarvard, Stig (1999) TV-nyheder i konkurrence [Television news under competition], Frederiksberg: Samfundslitteratur.

Jaworski, Adam; Fitzgerald, Richard, \& Morris, Deborah (2003) Certainty and speculation in news reporting on the future: the execution of Timothy McVeigh. Discourse Studies 5: 33-49.

Kroon Lundell, Åsa (2010) Dialogues between journalists on the news: The intraprofessional 'interview' as a communicative genre. Media Culture and Society 32: 429-450.

Kroon Lundell, Åsa, \& Ekström, Mats (2013) Interpreting the news: Swedish correspondents as expert sources 1982-2012. Journalism Practice 7: 517-532.

Kroon Lundell, Åsa, \& Eriksson, Göran (2010) Interviews as communicative resources in news and current affairs broadcasts. Journalism Studies 11: 20-35.

Labov, William (1972) Language in the inner city, Philadelphia: University of Pennsylvania Press.

Labov, William (1997) Some further steps in narrative analysis. Journal of Narrative and Life History 7 : 395-415.

Labov, William \& Waletzky, Joshua (1967) Narrative analysis: Oral versions of personal experience. In: Helm June (ed.) Essays on the verbal and visual arts. Seattle: University of Washington Press, 12-44.

Langer, John (1998) Tabloid Television: Popular Television and the "Other News", London: Routledge.

Larsen, Peter Harms (1995) Faktion - som udtryksmiddel [Faction - as a means of expression], Copenhagen: Forlaget Amanda.

Larsen, Peter Harms (2003) De levende billeders dramaturgi. Bind 2: TV [Dramaturgy of the moving pictures: Television], Copenhagen: DR Multimedie.

Larsen, Rasmus Sylvest \& Frederiksen, Kristian (2014) Skarpt skåret-sådan fortceller du en tv-historie [Sharply cut - this is how you tell a television story], Århus: Ajour.

Lewis, Justin (1994) The Absence of Narrative: Boredom and the Residual Power of Television News. Journal of Narrative and Life History 4: 25-40.

Machill, Marcel; Köhler, Sebastian; \& Waldhauser, Markus (2007) The Use of Narrative Structures in Television News. An Experiment in Innovative Forms of Journalistic Presentation. European Journal of Communication 22: 185-205.

Martin, James Robert \& Rose David (2008) Genre relations: Mapping culture, London: Equinox Pub.

Montgomery, Martin (2007) Discourse of broadcast news: a linguistic approach, USA and Canada: Routledge.

Morse, Margaret (1985) Talk, talk, talk. Screen 26: 2-17.

Neiger, Motti (2007) Media oracles: The cultural significance and political import of news referring to future events. Journalism 8: 309-321.

Pedersen, Christian Grunert (2013) Tv-nyheder taber 500.000 seere [Television news loses 500,000 viewers]. MEDIAWATCH 19.12.13, Available at: http://mediawatch.dk/Medienyt/TV/article6348109.ece

Salgado, Susanna \& Strömbäck, Jesper (2012) Interpretive journalism: A review of concepts, operationalizations and key findings. Journalism 13: 144-161.

Sand, Gunnar, \& Helland, Knut (1998) Bak TV-nyhetene: Produksjon og presentasjon i NRK og TV 2 [Behind the television news: Production and presentation in NRK and TV 2], Norway: Fagbokforlaget.

Scannell, Paddy (1996) Radio, Television, and Modern Life, Oxford: Blackwell.

Schudson, Michael (1982) The Politics of Narrative Form: The Emergence of News Conventions in Print and Television. Dadalus 111: 97-112.

Snoeijer, Roland; de Vreese, Claes H. \& Semetko, Holli A. (2002) Research Note: The Effects of Live Television Reporting on Recall and Appreciation of Political News. European Journal of Communication 17: 85-101.

Tolson, Andrew (2006) Media talk: Spoken discourse on TV and radio, Edinburgh: Edinburgh University Press.

Van Dijk, Teun A. (2008) Discourse and context. A Sociocognitive Approach, Cambridge: Cambridge University Press.

Ytreberg, Espen (2001) Moving out of the Inverted Pyramid: narratives and descriptions in television news. Journalism Studies 2: 357-371.

KENNETH REINECKE HANSEN, Ph.D., Assistant Professor, Centre for Journalism, University of Southern Denmark, krh@journalism.sdu.dk

PETER BRO, Ph.D., Professor, Centre for Journalism, University of Southern Denmark, ppe@journalism.sdu.dk

RALF ANDERSSON, Journalistic Lecturer, Centre for Journalism, University of Southern Denmark, raan@journalism.sdu.dk 